\section{K= Journals \\ ON-LINE \\ Publishers since 1933}

(C) Kamla-Raj 2007
ISSN $0970-9274$

JOURNAL OF HUMAN ECOLOGY

J. Hum. Ecol., 21(3): 173-180 (2007)

\title{
Cataract Blindness Among Scheduled Tribes in Mysore District, Karnataka: Problems and Perspectives
}

\author{
C. K. Kantharaju* and H.K. Bhat \\ Department of Studies in Anthropology, University of Mysore, Mysore 570 006, \\ Karnataka, India \\ *E-mail: kantharajuck_2002@hotmail.com
}

KEYWORDS Cataract Blindness, H.D. Kote Taluk, Tribal Settlements (Hadis), Bettakuruba, Jenukuruba, Yerava

\begin{abstract}
In the present study an attempt is made to understand the problems and perspectives of cataract blindness among Scheduled Tribes in H.D. Kote Taluk, Mysore District, Karnataka. The members of Scheduled tribes covered in the study are Jenukurubas, Bettakurubas and Yeravas. Ten tribal settlements known as hadis were selected for the present study. These settlements are located in the fringe area of Rajiv Gandhi National Park, Nagarahole. In-depth interviews were conducted on 160 informants, 80 males and 80 females. Out of 80 females 28 were suffering from cataract blindness and remaining were healthy individuals. Out of 80 males, 31 were suffering from cataract blindness and remaining were healthy persons. In the present study the emic perspective frequently mentioned is 'not able to see properly' (126). The major signs and symptoms of cataract blindness recorded are 'foggy vision' (99), and 'abnormal muscular growth over the eyes' (62). The constraints for underutilization of eye care services among members of scheduled tribes were 'no money (137), 'fear of surgery or treatment' (79), 'lack of information on eye care services' (61) and 'lack of family members who are willing to help the blinds to get treatment' (51). The major causes of cataract blindness recorded are 'carrying heavy load of firewood on head' (59), 'aging' (47) and 'not oiling the hair regularly' (46) according to the present study.
\end{abstract}

